\title{
Improving Work Efficiency and Productivity with Line Balancing and TPS Approach and Promodel Simulation on Brush Sub Assy Line in Automotive Companies
}

\author{
Jakfat Haekal
}

\author{
Department of Industrial Engineering, Universitas Mercu Buana \\ DKI Jakarta, Indonesia
}

Corresponding author details: Jakfat Haekal; jakfat.haekal@mercubuana.ac.id

\begin{abstract}
From Gaikindo's data, the impact of the covid-19 effect caused the automotive industry to experience a 50\% contraction; PT Denso Indonesia, which is an automotive component company, felt the impact where actual production fell by $30 \%$ in the first quartile of 2020, the company's adaptation was efficiency and productivity and activity cost down. The problem with the starter line is that there is a difference in the cycle time of each post in the sub-assy starter brush line, too gaping.

From this problem, the researchers analyzed with the TPS and Line Balancing methods with the help of pro model simulations, from these activities evaluated the performance line from the previous line efficiency of 89.05\% Balance Delay: 10.95\% and Smoothie Index 12.58 improved to line efficiency of 93.59\% Balance Delay: 6.35\% and Smoothie Index 6.10. However, there are still bottlenecks, following which improvements will be made using line balancing with pro model simulations; pro model simulations were chosen because to make repairs, it is enough to use the help of applications that are in line with the goals of the company, which is currently survival amid this intense competition.

After the repair was done using the Helgerson Bernie approach, a simulation of the line balancing method improvement was carried out. The line efficiency value was 95.76\% Balance Delay: 4.24\% and Smoothie Index 4.45 with a total outflow of 131 units of goods every 1 hour.
\end{abstract}

Keywords: efficiency and productivity; toyota production system; line balancing; promodel simulation

\section{INTRODUCTION}

The national automotive industry felt the impact of the Covid-19 outbreak. Data can see from the decline in demand for motor vehicles in Indonesia. The Association of Indonesian Automotive Industries (Gaikindo) submitted a correction to the sales target in 2020, estimated to experience a contraction of $50 \%$ due to lower domestic and foreign demand. The Ministry of Industry asked local governments not to limit industrial activities. As a result, car sales in Indonesia weakened during the first three months of this year. The sharp decline began in March. Based on data from the Association of Indonesian Automotive Industries (Gaikindo), total car sales during January-March this year were only 236,825 units, down 6.9 percent or more than 17 thousand units from last year's 254,332 units. When viewed by month, car sales began to fall in March. Realized sales were only 76,800 units, down $15.01 \%$ compared to the same month last year. Sales decline also occurred in January and February, namely 2.1 and $2.6 \%$, respectively.

This requires businesses in the automotive sector to emphasize competitiveness and seek ways to increase productivity by utilizing their resources more efficiently. The automotive industry in creating a competitive advantage is a factor that must be considered to survive and compete in times like this. The automotive industry's strategy in increasing productivity cannot be separated from its ability to manage its resources effectively and efficiently.
P.T. Denso Indonesia is a joint venture company between a holding company headquartered in Japan and PT Astra International Tbk in the PT Astra Otoparts Tbk group, engaged in manufacturing automotive components, with products such as Spark Plugs, Car / Bus / Truck A.C., Radiators, ECUs., Meter

Cluster, Starter, Alternator, VCT, 02 Sensor, and others. Founded in 1975 in Sunter, North Jakarta, it has now developed into a Group Company called the D.I. The group with a total number of employees in early 2020 has reached more than 6,000 employees.

At the beginning of the 2020 Quartil, the company must survive due to sufficient contraction due to the impact of Covid19. Therefore, the company has several target activities plans of the several targets; P.T. Denso Indonesia has one of the targets, among others, productivity improvement. The company continues to strive to increase productivity because productivity is one aspect that determines the level of success of a company competing in an increasingly tight industrial world. Furthermore, the productivity achieved by a company is an indicator of how efficient the company is in combining its current economic resources.

The starter is one of the products from P.T. D, which is the main component of the four wheels as a starting engine, 
and the five main components of the starter/sub assy, namely 1. Magnetic switch S / A, 2. Yoke S / A / Stator, 3. Armature S / A / Rotor, 4. Cluth S / A and 5. Brush S / A. The research itself was carried out in the line brush sub assy; the brush itself has two general models, namely LS and PA64LL; L.S. itself is a conventional starter product of the planetary model used in passenger vehicles commonly found in Indonesia and several neighboring countries. The PA64LL type is a refinement of the L.S. model whose products are applied in modern and future cars.
In collecting data in the field for the PA64LL model, there was a problem finding in the form of a difference in the cycle time subassy to the assy line where the subassy brush was 30 seconds with seven manpower and 13.7 seconds of the assy line. Although the accumulative production plaining for the PA64LL model is 5\% of the total production, the following creates a potential supply delay problem. The following is table 1 an explanation of the level of time sub assy to assy.

TABLE 1: Production in December 2019 - January 2020

\begin{tabular}{|l|c|c|c|c|c|}
\hline \multicolumn{1}{|c|}{ DESCRIPTION } & DEC & JAN & FEB & MAR & AVE \\
\hline Total Prod PA64LL & 4,140 & 2,080 & 1,620 & 980 & 2,205 \\
\hline Grand Total Prod & 64,185 & 46,538 & 38,782 & 14,617 & 41,031 \\
\hline
\end{tabular}

TABLE 2: Production Review December 2019 - January 2020

\begin{tabular}{|c|c|c|c|c|c|c|c|c|c|}
\hline \multirow{2}{*}{ No } & \multirow{2}{*}{ Line } & \multirow{2}{*}{ Man Power } & \multicolumn{2}{|c|}{ CT (Sec) } & \multicolumn{2}{|c|}{ Qty (Pcs) } & \multirow{2}{*}{ LOR (\%) } & \multirow{2}{*}{ CT kajuheki } & \multirow{2}{*}{ Result } \\
\hline & & & $\mathrm{L} / \mathrm{S}$ & PA64LL & $\mathrm{L} / \mathrm{S}$ & PA64LL & & & \\
\hline 1 & Final assy & 7 & \multicolumn{2}{|c|}{14.7} & 40030 & 3205 & 88.6 & 14.7 & 0 \\
\hline 2 & Clutch & 7 & \multicolumn{2}{|c|}{14.5} & 41030 & 3205 & 88.7 & 14.5 & $\mathbf{0}$ \\
\hline 3 & Motor & 3 & \multicolumn{2}{|c|}{14.5} & 41030 & 3205 & 91 & 14.5 & $\mathbf{0}$ \\
\hline 4 & Armature & 6 & \multicolumn{2}{|c|}{14.7} & 41030 & 3205 & 88 & 14.7 & $\mathbf{0}$ \\
\hline 5 & Mg.switch & 7 & \multicolumn{2}{|c|}{13.7} & 42030 & 3205 & 89.2 & 13.7 & $\mathbf{0}$ \\
\hline 6 & Brush & 7 & 13.7 & 30 & 41030 & 3205 & 87.2 & 14.9 & $\mathbf{X}$ \\
\hline
\end{tabular}

The data in Table 1 explains that

1) The sub-assy brush has two patents, namely 13.7 for the LS model and 30 for the PA64LL model, where the CT kajuheki is 14.9

2) There are two types, namely LS and PA64LL, with each request being different for each class.

3) LOR is the Line Operational Ratio (line productivity ability)
Line brushes are not targeted due to the existence of a functional bottleneck element and the working time of each manpower, so it refers to the company's target of productivity efficiency to increase productivity at PT. Denso Indonesia, especially in the production of the Starter line Brush for the PA64LL model with a cycle time of 30 seconds and 7 Manpower which produces an output of 108 products per hour, therefore increasing the productivity of PT. Denso Indonesia continues to strive and has a target to manage resources effectively and efficiently by optimizing work elements and the number of manpower in each production process. And from the data collection for the cycle time of each post, there is a big difference where the following is a waste and must be corrected; Figure 1 describes the cycle time of each post.

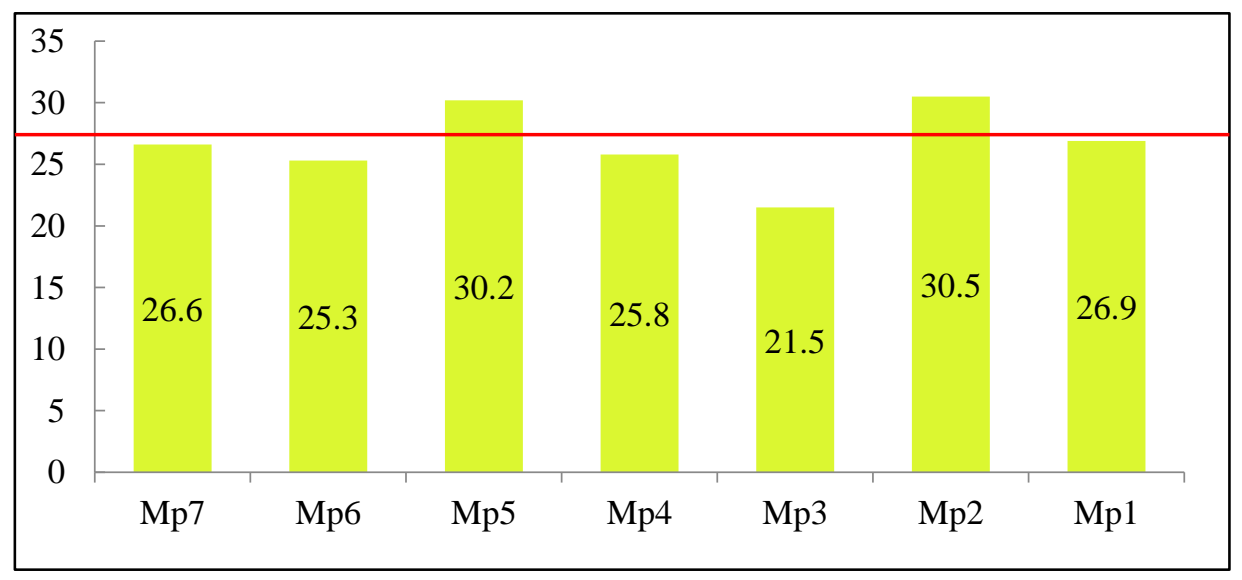

FIGURE 1: Yamazumi Chart Line Brush 
The data in Figure 1 explains that:

1) There are 7 Man Power (MP).

2) The highest CTs are at MP nos. 2 and 5.

3) 3.The lowest CT is at MP No.3.

4) Target 27 seconds from the company

With these problems and targets, a method of equal distribution of work elements and work efficiency is needed to continue to work comfortably so that the company's marks can be achieved. One of the things that can be done is reducing idle time (youth), increasing efficiency, and leveling the production line using the line balancing method and using the TPS method. Moreover, according to (Harrell, C., Ghosh, BK, \& Bowden, R 2004) in his book Simulation Using Promodel says that to be able to make a design to make simulation decisions can also be used to validate findings made validation of this decision means whether the decision that is taken is the best. Simulation can also reduce costs because it does not take a long time than trial and error techniques. The strength of simulation lies in the availability of analytical methods that are formal and predictive and accurately predict the performance of even the most complex systems.

Increased efficiency and productivity can also be supported by reducing youth and modifying the operator's work elements to make it more effective, efficient, safe, and comfortable. Then the way that can be used to eliminate youth and increase productivity, the approach used is the Toyota Production System (TPS); TPS is a system developed by Taichi Ohno in 1950 and has been successfully implemented in the Toyota company, this system is the main factor that makes the company Toyota was so successful. The main idea of TPS is to eliminate waste to find potential problems by reducing inventory, and to explore fundamental issues and organize them in organizational culture; TPS makes continuous improvements, two critical factors at TPS are just in time (JIT) and Jidoka (Liker \& Meier, 2006). TPS has the main objective of reducing costs or improving productivity. Cost reduction and productivity improvements are achieved by eliminating various wastes, such as changing manual handling tools. Therefore, TPS is an approach that will be used as the basis for steps in increasing productivity in the Sub Assy brush line production.

This research focuses on increasing productivity by carrying out resource efficiency in the Sub Assy brush line PT production process. Denso Indonesia. Researchers use line balancing and TPS methods; with line balancing methods, it can be seen that the cycle time at each post and work element can also be used to equalize cycle time by analyzing work elements and selecting and dividing work elements, and the application of TPS which will have an impact on increasing efficiency and increased productivity through savings in production time. As well as finding and reducing youth and standardizing work with the TPS system approach. This method is expected to achieve one of the company's targets in 2020 at PT. Denso Indonesia.

\section{RESEARCH METHODOLOGY}

\section{- Types of Data and Information}

Types of data and information used in this study are primary data and secondary data. This definition is described as follows.

\section{Primary data}

According to Hasan (2002), data is obtained or collected directly in the field by conducting the research or those concerned who need it. Therefore, the primary data used in this study are: (a) The results of research interviews conducted by the production division, production engineer, and TIE.

(b) The results of field observations made by researchers who took operator CT data in line brushes and other supporting data.

\section{Secondary Data}

Secondary data is data obtained or collected by people researching existing sources (Hasan, 2002). Secondary data in this study include:

(a) General information about the company

(b) Production planning data and actual production

(c) SWC line brush for the PA64LL model

(d) Line brush operation ratio

(e) Research supporting data (literature, books, journals, etc.)

\section{- Data Collection Methods}

Here the author will explain the procedures and data collection techniques used in this study:

\section{Interview (Interview)}

According to Sugiyono, the interview is a data collection technique carried out in a structured or unstructured manner. It can be done face-to-face or in person or by using a telephone network. In this study, interviews were carried out by conducting dialogue with production division staff (Dafmiko, Sapiih, Fendi), production engineers (Eka), and TIE (Mario), and related employees to obtain information and data needed in matters relating to problems. Research.

\section{Field Study (Observation)}

Field studies were carried out to obtain primary data as actual data related to research, which was carried out by gaining access to retrieve real data on the fabrication process.

\section{Literature Study (Literature)}

Done to obtain secondary data, sourced from companies, journal articles, training materials, and others that are still related to research

\section{- Data Processing and Analysis Methods}

After obtaining all the required data, the data processing is carried out with the data processing used in this study is the Toyota Production System concept with the Line Balancing method, which is used as the basis for steps to increase productivity using the pro model simulation:

\section{Production System Analysis}

At the analysis stage of the production system in research on line brush sub assy at PT D, the following steps of analysis were carried out:

(a) The production line runs on a brush line with type PA64LL

(b) The processing time of each station

\section{Analysis between measurement results with SWC}

(a) SWC analysis

The Standardized Work Chart (SWC) will make it easier for researchers to understand the conditions/processes of each work element from start to finish, making it easier to find out what the current work process is and where the waste is. In addition, this SWC shows the time needed in each functional element in one cycle. With this, it will be easy to identify which waste is in which area or process.

Analyzing the SWC is based on the data obtained in the field, namely the process movement of each process from the beginning of the initial training to the final action, then calculating the total time or study time and determining how much time has added value and time that has no 
added value with what is then poured in the form of a yamazumi chart.

\section{(b) Problem Identification}

At this stage, the identification of work elements during the process, each process's activity, the cycle time of the assembling process, and the need for manpower in each activity, and other process data are carried out. Furthermore, identifying problems that most influence the process is carried out by looking at the seven waste factors (Over Production, Waiting Time, Transportation, Over processing, Motion, Inventor \& Defects).

(c) Create a yamazumi chart

After getting the weight of each process, the next step is to create a yamazumi chart. The weight calculation on this Yamazumi chart is done by measuring the cycle time of each method. Here it will be known which waste affects the delay in the process in the line brush sub assy.

(d) Knowing the cycle time of each Work Station The first step in Line Balancing is knowing the Takt Time for each Workstation.

\section{(e) Create Process Details}

To ensure balance, it is essential to understand the relationships and sequences between various tasks. Therefore, make a detailed process that identifies the connection and line between the processes involved.

(f) Idle Time

Idle time is the difference or difference between Cycle

Time (CT) and Station Time (ST), or CT minus ST (Baroto, 2002).

(g) Balance Delay

Balance Delay measures path inefficiency resulting from actual idle time caused by imperfect allocation between work stations.

\section{RESULT AND DISCUSSION}

\section{- Analysis of Conditions Before After and Proposals}

This chapter will explain the conclusions of the results of data processing from the previous chapter, where the results and discussion will be explained in this chapter, here is an analysis of conditions before any improvement in the form of SWC data from line brushes.

\section{SWC before and after repair}

Here will explain the differences that will be made improvements and what is taken is the post which is the bottle next and the following is the SWC from post 2.

(a) SWC before repair

Heading 2 as follows (h) Work Station Efficiency

Workstation efficiency is the ratio between each Workstation's operating time (Wi) and the most oversized Workstation (Ws) running time.

(i) Line Efficiency

Line Efficiency is the ratio of the total workstation time Baroto (2002) or the number of workstation efficiency divided by the number of work stations (Nasution, 1999).

(j) Smoothest Index

Smoothest Index is an index that shows the relative smoothness of balancing a particular assembly line.

(k) Work Station

The Work Station is a place on the assembly line where the assembly process is carried out. After determining the cycle time interval, the number of workstations is efficient

(l) Analyze and Perform Balancing Actions

After identifying the station that has a time difference with the specified cycle time, perform a workload balancing act so that the Workstation's total cycle time is lower than the entire cycle time of the fixed Workstation.

(m) Simulation of ideas and proposals with Promodel The analysis is simulated and demonstrated using the Promodel application to present the proposed problems' results and ideas on the line brush sub assy. The results will be evaluated.

(n) Evaluation and Results

From the results of the pro model, it can be seen that from the ideas and proposals, it can be proposed to improve the sub-assy line brush to improve the performance line, which can then be carried out real improvements. divided by the cycle times the number of work stations

TABLE 3: SWC Pos 2 Before Repair

\begin{tabular}{|c|c|l|c|c|c|}
\hline Asociate & Sequence & \multicolumn{1}{|c|}{ Element work } & HT & MT & Net \\
\hline 2 & 1 & Ta: Take crocodile pliers / 30 pcs & 0.1 & & 0.1 \\
\hline 2 & 2 & $\begin{array}{l}\text { Ti: Take the S / A brush from the } \\
\text { pallet. Ta, bend the direction of the } \\
\text { pigtail brush with the crocodile head }\end{array}$ & 8.3 & 8.4 \\
\hline 2 & 3 & $\begin{array}{l}\text { Ti: place the bent S / A brush into the } \\
\text { F / G palette }\end{array}$ & 1.8 & 10.2 \\
\hline 2 & 4 & $\begin{array}{l}\text { Ti: Take the S / a brush from the } \\
\text { pallet, bend the direction of the pigtail } \\
\text { brush with alligator pliers }\end{array}$ & 8.3 & 18.5 \\
\hline 2 & 5 & $\begin{array}{l}\text { Ti: place the bent brush s / a onto the } \\
\text { F / G pallet }\end{array}$ & 1.8 & 20.3 \\
\hline 2 & 6 & $\begin{array}{l}\text { Ti: Take the S / A bush from the } \\
\text { pallet, Ta: bend the direction of the } \\
\text { pigtail with alligator pliers }\end{array}$ & 8.3 & 28.6 \\
\hline 2 & 7 & $\begin{array}{l}\text { Ti Place the bent S / A brush onto the } \\
\text { F / G pallet }\end{array}$ & 1.8 & & 30.4 \\
\hline 2 & 8 & \begin{tabular}{l} 
Ta: put alligator pliers / 30 pcs \\
\hline
\end{tabular}
\end{tabular}


In post 2 one process is 30.5 seconds where it is the bottle neck of the PA64LL type brush line process and the next bottle neck is in post 5 and as is the SWC from post 5

TABLE 4: SWC Pos 5 Before Repair

\begin{tabular}{|c|c|c|c|c|c|}
\hline Asociate & Sequence & Element work & HT & $M T$ & Net \\
\hline 5 & 1 & $\begin{array}{l}\text { Ti: take the plate and place it in the left } \\
\text { hand }\end{array}$ & 2.0 & & 2.0 \\
\hline 5 & 2 & $\begin{array}{l}\text { Ti: Hold the plate, Ta: Take and attach } \\
\text { the brush assy to the plate manually }\end{array}$ & 5.8 & & 7.8 \\
\hline 5 & 3 & $\begin{array}{l}\text { Ti: Hold the plate, Ta: Take and attach } \\
\text { the brush assy to the plate manually }\end{array}$ & 5.8 & & 13.6 \\
\hline 5 & 4 & $\begin{array}{l}\text { Ti: Hold the plate, Ta: Take and attach } \\
\text { the brush assy to the plate manually }\end{array}$ & 5.8 & & 19.4 \\
\hline 5 & 5 & $\begin{array}{l}\text { Ta Ti: Attach the brush assy plate to } \\
\text { the empty pallet }\end{array}$ & 4.8 & & 24.2 \\
\hline 5 & 6 & $\begin{array}{l}\text { Ti: pull out and slide F / G pallet from } \\
\text { M / C welding until it is stuck, Ta: Push } \\
\text { pallet to front M / C welding }\end{array}$ & 2.0 & & 26.2 \\
\hline 5 & 7 & Ta: push the pallet into M / C welding & 1.0 & & 27.2 \\
\hline 5 & 8 & $\begin{array}{l}\text { Ti Ta: Take the brush assy from the } \\
\text { pallet, Ti: Put it in the WIP next } \\
\text { process }\end{array}$ & 2.0 & & 29.2 \\
\hline 5 & 9 & $\begin{array}{l}\text { Ti: Move the empty pallet to the home } \\
\text { post, Ta: Switch area }\end{array}$ & 1.0 & & 30.2 \\
\hline
\end{tabular}

The standard time in Post 5 is 30.2 where both posts are bottle next so the first thing is to implement the TPS method with the application of kaizen. With the idea of improvement in post 5 , namely making a pusher jig and post 2 , namely making a jig for bending, the SWC changes in post 5 and post 2 are obtained as beirekut:

(b) SWC after repair at post 2

TABLE 5: SWC Pos 2 After Repair

\begin{tabular}{|c|c|l|c|c|c|}
\hline Asociate & Sequence & \multicolumn{1}{|c|}{ Element work } & HT & MT & Net \\
\hline 2 & 1 & $\begin{array}{l}\text { Ti : Ambil brush assy pada pallet, } \\
\text { Kemudiansetting ke jig assy dan lakukan } \\
\text { manual bending }\end{array}$ & 2.5 & 2.4 \\
\hline 2 & 2 & $\begin{array}{l}\text { Ta: Ambil dan pasang Brush assy ke jig } \\
\text { press }\end{array}$ & 2.3 & 4.7 \\
\hline 2 & 3 & $\begin{array}{l}\text { Ti : Ambil brush assy pada pallet, } \\
\text { Kemudiansetting ke jig assy dan lakukan } \\
\text { manual bending }\end{array}$ & 2.5 & 7.2 \\
\hline 2 & 4 & $\begin{array}{l}\text { Ta: Ambil dan pasang Brush assy ke jig } \\
\text { press }\end{array}$ & 2.3 & 9.5 \\
\hline 2 & 5 & $\begin{array}{l}\text { Ti : Dorong jig press, Ta : tekan tuas } \\
\text { mekanik }\end{array}$ & 2.0 & 11.5 \\
\hline 2 & 6 & $\begin{array}{l}\text { Ta: Lepas tuas manual press, Ti : Tarik } \\
\text { jig press }\end{array}$ & 2.0 & 13.5 \\
\hline 2 & 7 & $\begin{array}{l}\text { Ta Ti : Ambil dan Setting Brush Assy }(2 \\
\text { pcs) ke Pallet fG }\end{array}$ & 3.4 & 16.9 \\
\hline 2 & 8 & $\begin{array}{l}\text { Ti : Ambil brush assy pada pallet, } \\
\text { Kemudiansetting ke jig assy dan lakukan } \\
\text { manual bending }\end{array}$ & 2.5 & 19.4 \\
\hline 2 & 9 & $\begin{array}{l}\text { Ta: Ambil dan pasang Brush assy ke jig } \\
\text { press }\end{array}$ & 2.3 & & 21.7 \\
\hline 2 & 10 & $\begin{array}{l}\text { Ti : Dorong jig press, Ta : tekan tuas } \\
\text { mekanik }\end{array}$ & 1.0 & 22.7 \\
\hline 2 & 12 & $\begin{array}{l}\text { Ta: Lepas tuas manual press, Ti : Tarik } \\
\text { jig press }\end{array}$ & $\begin{array}{l}\text { Ta Ti : Ambil dan Setting Brush Assy }(1 \\
\text { pcs) ke Pallet fG }\end{array}$ & 1.0 & 23.7 \\
\hline
\end{tabular}

From the activity of adding the bending jig to post 2, the default time can be reduced from 30.5 to 25.5 and the following is the kaizen result post from heading 5 . 
TABLE 6: SWC Pos 5 After Repair

\begin{tabular}{|c|c|c|c|c|c|}
\hline Asociate & Sequence & Element work & HT & MT & Net \\
\hline 5 & 1 & $\begin{array}{l}\text { Ti: Ambil Plate dan posisikan di } \\
\text { tangan kiri }\end{array}$ & 2.0 & & 2.0 \\
\hline 5 & 2 & $\begin{array}{l}\text { Ti: tahan Plate, ta: ambil dan pasang } \\
\text { brush assy ke plate }\end{array}$ & 2.1 & & 4.1 \\
\hline 5 & 3 & $\begin{array}{l}\text { Ti: tahan Plate, ta: ambil dan pasang } \\
\text { brush assy ke plate }\end{array}$ & 2.1 & & 6.2 \\
\hline 5 & 4 & $\begin{array}{l}\text { Ti: tahan Plate, ta: ambil dan pasang } \\
\text { brush assy ke plate }\end{array}$ & 2.1 & & 8.3 \\
\hline 5 & 5 & $\begin{array}{l}\text { Ta Ti: Setting Plate Brush Assy ke Jig } \\
\text { Press }\end{array}$ & 3.8 & & 12.1 \\
\hline 5 & 6 & $\begin{array}{l}\text { Ta Ti: Manual Pres brush dengan jig } \\
\text { (3 pcs) }\end{array}$ & 2.5 & & 14.6 \\
\hline 5 & 7 & $\begin{array}{l}\text { Ta Ti: Buka lock press brush dengan } \\
\text { jig ( } 3 \text { pcs) }\end{array}$ & 2.5 & & 17.1 \\
\hline 5 & 8 & $\begin{array}{l}\text { Ta Ti: ambil Plate brush assy dari jig } \\
\text { press }\end{array}$ & 1.0 & & 18.1 \\
\hline 5 & 9 & $\begin{array}{l}\text { Ti Ti: Pasang M-Rubber ke Jig MC } \\
\text { Projection }\end{array}$ & 2.5 & & 20.6 \\
\hline 5 & 10 & $\begin{array}{l}\text { Ti: Tarik keluar dan geser pallet F/F } \\
\text { dari M/C welding sampai mentok, Ta: } \\
\text { Dorong pallet sampai depan M/C }\end{array}$ & 2.0 & & 22.6 \\
\hline 5 & 11 & Ta: Dorong pallet ke M/C welding & 1.0 & & 23.6 \\
\hline 5 & 12 & $\begin{array}{l}\text { Ti Ta: Ambil brush assy dari pallet, Ti : } \\
\text { Letakan di WIP nest proses }\end{array}$ & 2.0 & & 25.6 \\
\hline 5 & 13 & $\begin{array}{l}\text { Ti: geser palet ksoong ke Home posh, } \\
\text { Ta: Nagara switch }\end{array}$ & 1.0 & & 26.6 \\
\hline
\end{tabular}

Pos 5 is also being improved, namely adding a pusher jig so that plate installation can be done with tools and speed up the process, and from this activity it can reduce the standard time from 30.2 to 26.6 seconds.

\section{Yamazumi Chart before and after repairs}

(a) Yamazumi Before repair

From the following results, data processing is required, namely making a Yamazumi Chart before the line breeding is carried out, especially in posts 2 and 5.And here is the yamazumi line brush chart:

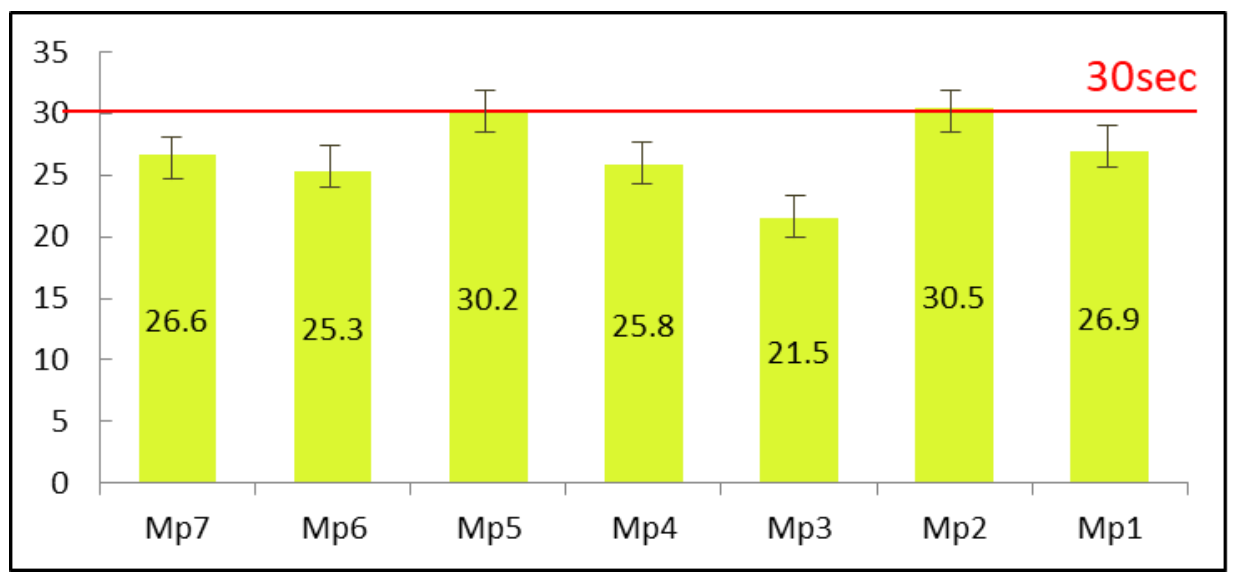

FIGURE 2: Yamazumi Chat Before Repair

It can be seen that there are significant / baratsuki differences between posts. Where posts 2 and 5 are the largest bottle necks and idles in post 3. 
- Yamazumi after repair

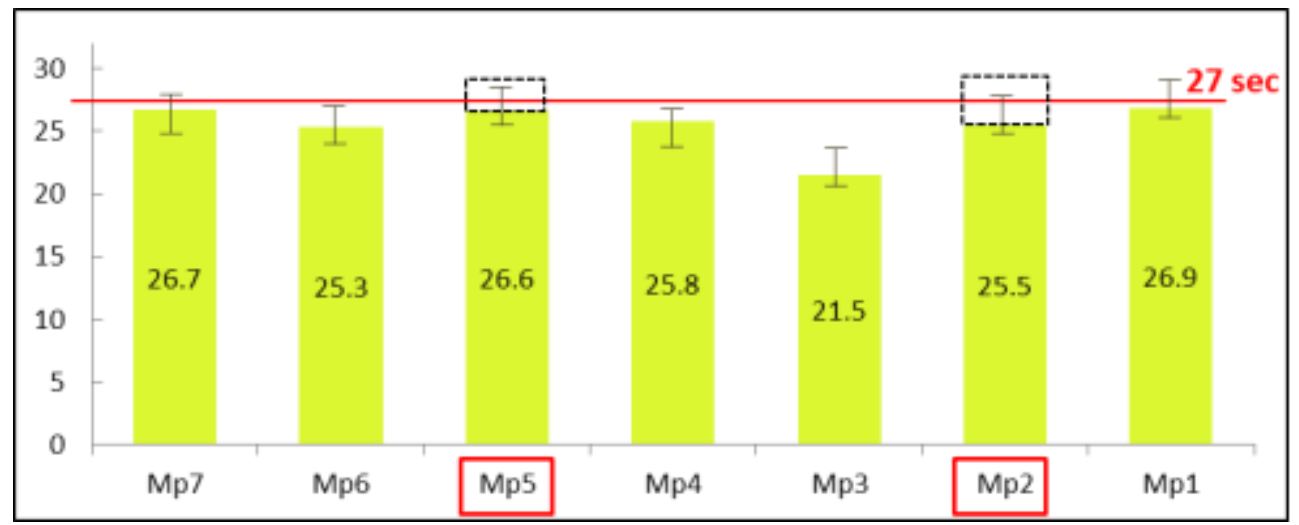

FIGURE 3: Yamazumi Chart After Repair

From table 3 it can be seen that after the repair, the line is able to run with a standard time of 27 seconds and even though the post 2 and post 5 improvements have been done, it still becomes a bottle neck and post 3 shows an idle post, but baratsuki is able to decrease and make the efficiency of the line improve and the value line efficiency, balance delay, and smoothing index.

Calculating line efficiency:

$=176.9 /(27 \times 7) \times 100 \%=93.59 \%$

Calculating Balance Delay:

$=(189-177) / 189 \times 100 \%=6.35 \%$

Calculates the Smootie Index

$=\sqrt{ }(0+1.69+29.16+1.21+0.09+2.56+2.56)$

$=6.10$

And the following is a comparison chart before and after improvements in line brushes by applying kaizen.

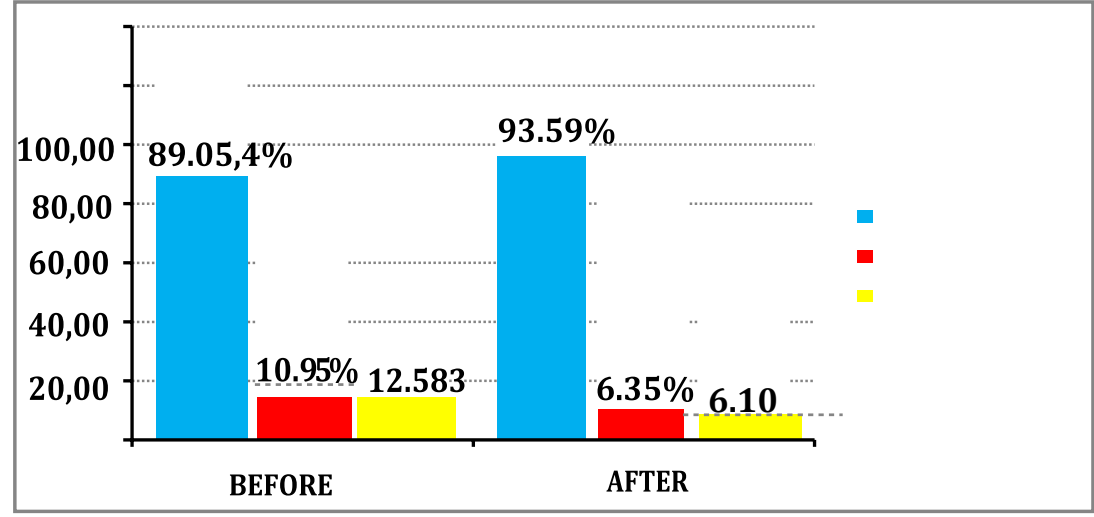

FIGURE 4: Line Brush Comparison Before and After Repair

It can be seen that from Figure 4 there is an improvement both in line efficiency and productivity where after correcting the standard time it can be reduced to 27 seconds, which was originally 30 seconds.

\section{- Proposed further improvements using the line balancing method}

After the improvement, it can be seen in 3 even though the efficiency and productivity have increased, but post 2 and post 5 are still becoming bottle necks. The next step is to provide a suggestion using the line balancing approach with the Bernei and Moodie Young methods where chapter 4 has been explained regarding data processing and this chapter will describe the results of data processing using the Helgeson-Birnie method as follows:

Calculating line efficiency:

$=178.3 /(26.6 \times 7) \times 100 \%=95.76 \%$

Calculating Balance Delay:

$=(186,2-178,3) / 186,2 \times 100 \%=4,24 \%$

Calculates the Smootie Index

$=\sqrt{ }(1.44+1.44+14.44+0.81+0.01+1.69+0)$

$=4.45$

And with the modie young method as follows:

Calculating line efficiency:

$=178.3 /(27 \times 7) \times 100 \%=94.34 \%$

Calculating Balance Delay:

$=(189-178) / 189 \times 100 \%=5.82 \%$

Calculates the Smootie Index

$=\sqrt{ }(0+1.69+29.16+1.21+0.09+2.56+0.04)$

$=5.89$ 
From the line balancing method approach, both of them have experienced an increase, but for the modie-young method it is not optimal because the process for the second phase cannot and the results of phases one and two are the same, then by comparing the two approaches, the following graph will be obtained:

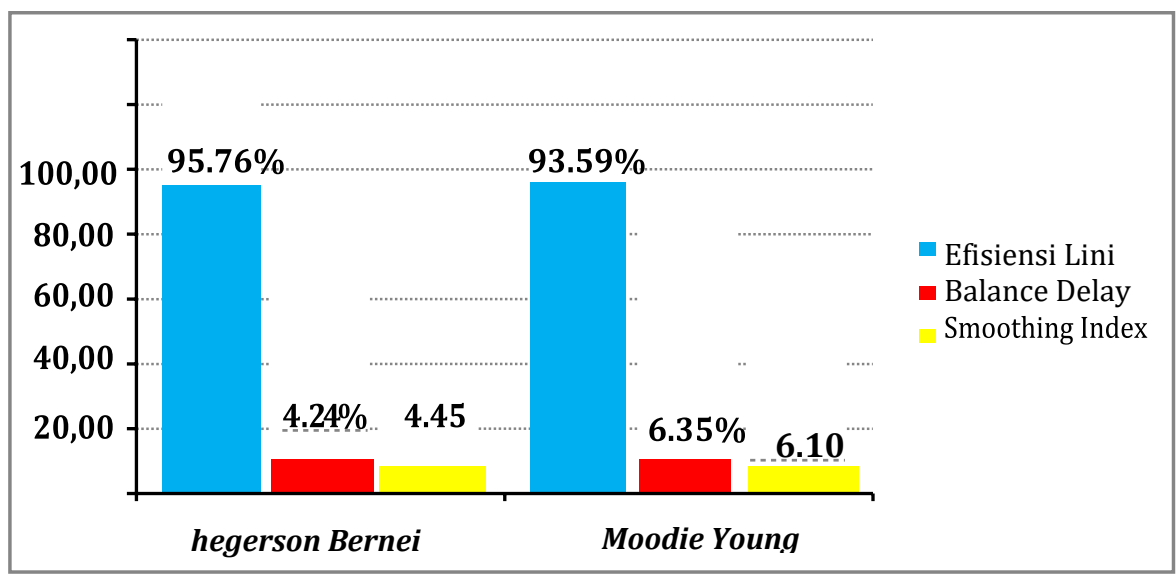

FIGURE 5: Comparison of Hegerson and Moodie Young

From Figure 5 and the calculation results, it is found that the hegerson bernei method was chosen because the calculation results are more than the modie young method using the following method, how much is the line efficiency at $95.76 \%$ with a delay of 4.24 and a smotie line of 4.45. For the case of different predence diagrams will produce different numbers, then from the calculation selected by the bernei method a simulation test will be carried out with the help of the Promodel application software.

\section{- Analysis of the Proposed Line Balancing Results using the Promodel}

This chapter will explain the analysis of the results of what has been done in the previous chapter. The analysis contains an explanation of the Promodel results as well as the figures obtained from the researchers' calculations obtained based on the method chosen in this study. At this stage we perform a model analysis using a time duration of 1 hour. The following is the data obtained after the model is run:

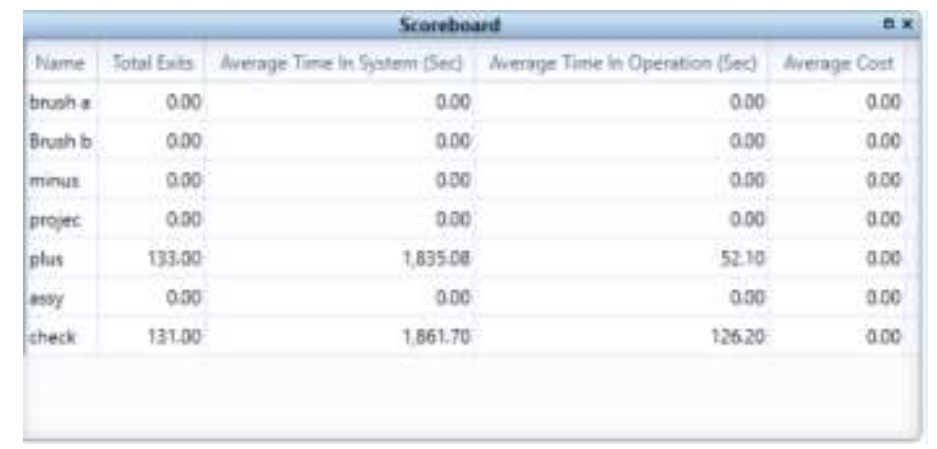

\section{Localication / location}

FIGURE 6: Promodel Results

\section{(a) Output}

The total exit check is the number of exits in the system. In this data it is analyzed that the total goods outgoing are 131 items with $100 \%$ capability in the system.

(b) Average time in processes (sec)

At this stage it is analyzed that the average processing time to finished goods is 126.2 seconds. While the average in system is $1,861.70 \mathrm{sec}$ with an outpurpose of 131 pieces.

(c) Utilisazien results

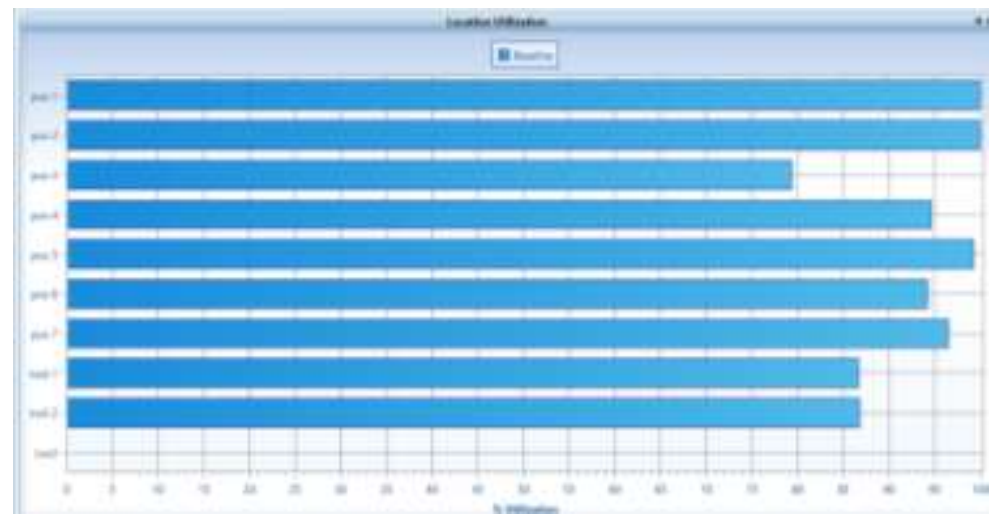

FIGURE 7: Ultilization Results 
At this stage, it is realized that the workload for each task at each post is as follows:

- post 1: $100.00 \%$

- post 2: $100.00 \%$

- post 3: 79.49\%

- post 4: $94.62 \%$

- post 5: $99.29 \%$

- post 6: $94.30 \%$

- post 7: $95.50 \%$

\section{Location State Multi}

Describes the use of capacity in locations with more than one capacity.

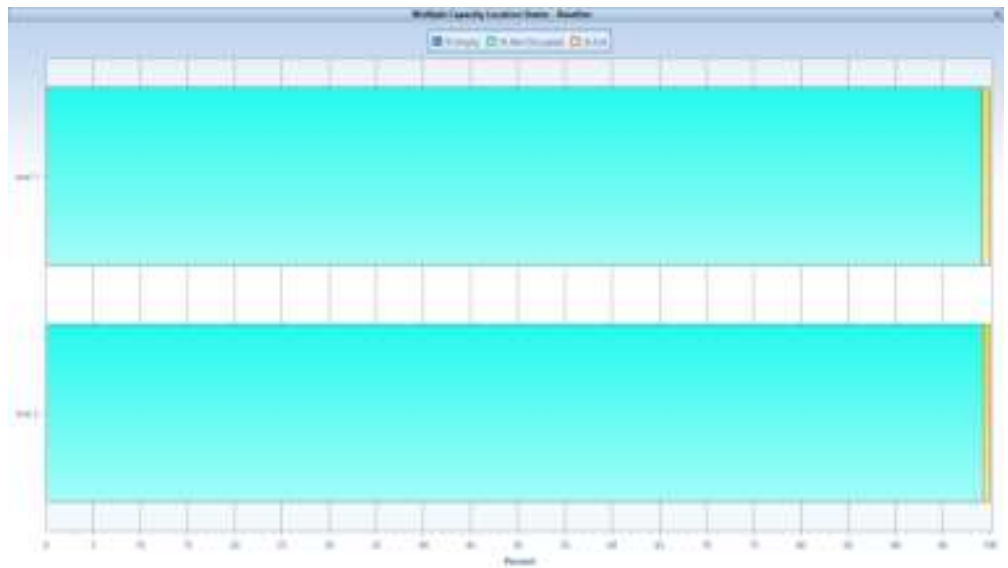

FIGURE 9: Location State Multi

In this system, using 2 arrival entities with multiple capacities in the model is trolley 1 and trolley 2 , within 1 hour the percentage is $99.29 \%$.

\section{Location State Single}

Describes the use of capacity with the same capacity

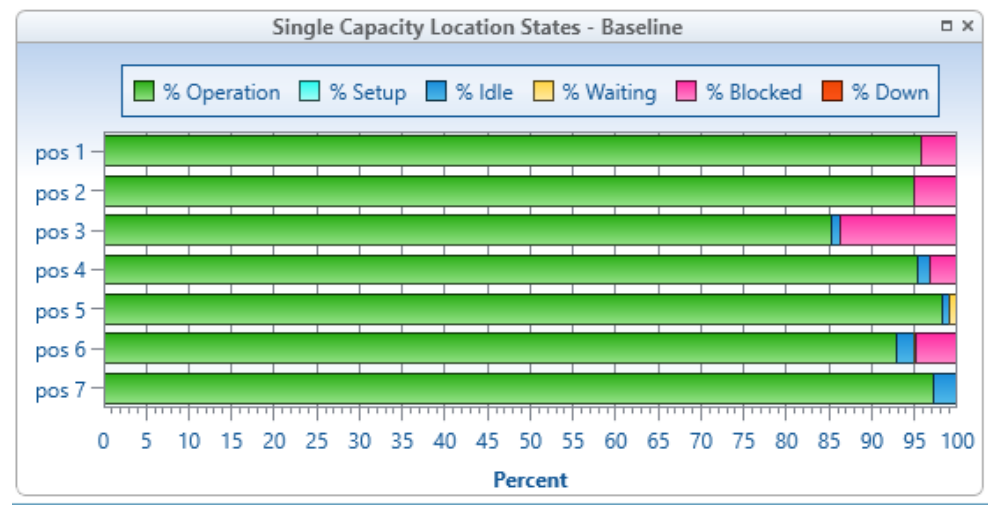

FIGURE 10: Location State Single

Locations that have a single capacity are as follows along with the details:

(a) Heading 1 namely

Has a working percentage: $95.70 \%$

Percentage held: $4.3 \%$

(b) Heading 2 namely

Have a working percentage: $94.9 \%$

Percentage held: 5.1\%

(c) Heading 3 namely

Has a working percentage: $85.32 \%$

Idle percentage: $0.94 \%$

Percentage held: $13.74 \%$

(d) Heading 4 namely

Has a working percentage: $95.39 \%$

Idle percentage: $1.34 \%$

Percentage withheld: $3.26 \%$ (e) Heading 5 namely

Has a working percentage: $98.35 \%$

Idle: $0.71 \%$

Wait: $0.94 \%$

(f) Heading 6 namely

Has a working percentage: $92.84 \%$

Idle: $2.008 \%$

Percentage held: $4.84 \%$

(g) Heading 7 namely

Has a working percentage: $75.24 \%$

Idle: $2.76 \%$

(h) Entity State

Describes the percentage of state entities in the system 


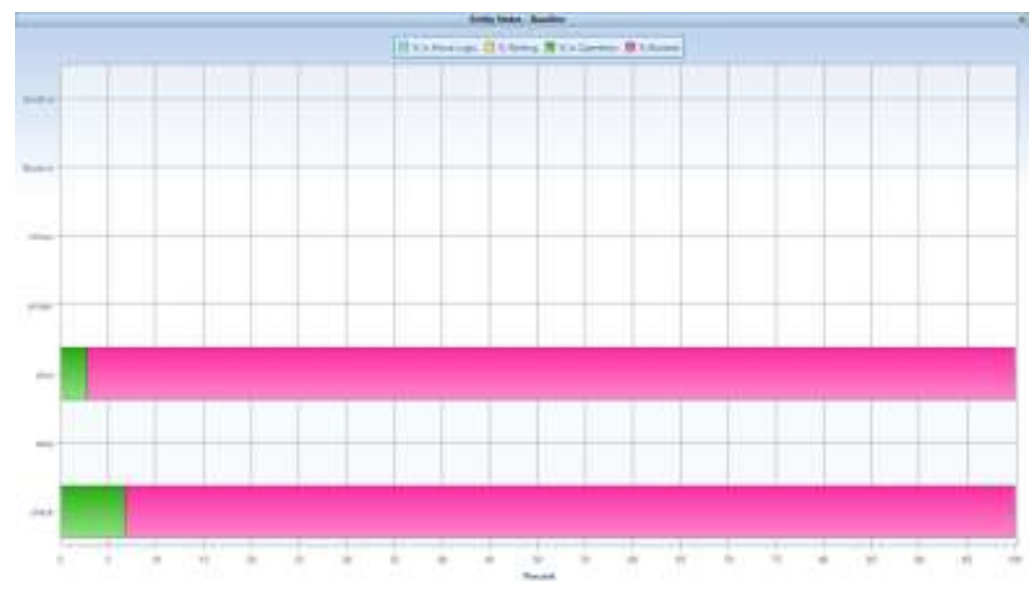

FIGURE 11: Entity State

From the figure, it can be seen that the check entity has an operational percentage of $6.78 \%$ and a retained percentage of $93.22 \%$

\section{CONCLUSION}

1. Based on the description of the analysis in this study, it is concluded that the increase in the efficiency and effectiveness of line brushes at PT Denso Indonesia has obtained the expected results. This can be seen from the results of the initial problem, namely the difference in cycle time, and some bottlenecks are too different from one post to another. The first improvement is to analyze the youth with the TPS method with the kaizen approach. The initial performance is line efficiency of 89.05\% Balance Delay 10.95\% and Smoothie Index 12.58 from the results of the analysis post two and post 3 are bottlenecks. From the analysis of post two and post 5 , the work element that causes height is a manual process, so from kaizen, what is done is to make a jig for post two and post 5 with line efficiency results of 93.59\% Balance Delay 6.35\% and Smoothie Index 6.10. After calculating, it can be seen that the yamazumi chart is getting better even though post two and post 5 are still bottlenecks and post 3 is still idle time on that line. Furthermore, analysis is carried out using the line balancing method with the approach used is Hegerson Bernie and Modie Young. The first step is to make tenderence data, then the data processing is carried out using the hegerson bernei and modie-young approach methods. The results obtained are hegerson with a line efficiency value of $95.76 \%$, Balance Delay $4.24 \%$, and Smoothie Index 4.45 .

2. The results of the proposed idea can address improvement by choosing the line balancing method with the Bernie hegerson approach.

3. Because it is better than using modie young supported by using the Promodel simulation application with line efficiency results of $95.76 \%$ Balance Delay: $4.24 \%$ and Smoothie Index 4.45 with promodel using the promodel result data, namely 10 locations, seven entities and arrival as many as two and processing is ten can be analyzed the total outflow of goods is 131 items with $100 \%$ capability in a system with a duration of 1 hour, in this simulation, it is analyzed that the average processing time until finished goods is 126.2 sec. At the same time, the average in the system is $1,861.70 \mathrm{sec}$.

\section{SUGGESTIONS}

Based on the results of research and discussion on increasing efficiency and productivity at PT Denso Indonesia with a research focus on line brush type PA64LL, the following suggestions can be made:
1. Implement improvements both with kaizen and line balancing with a promodel approach, the need for support from top management, and solid teamwork. The role of top management has the primary aspect, namely providing leadership and freedom to access data or explore related lines to be studied.

2. Creating a special team to analyze the line and focus on improving the performance line so that the waste in the line can be repaired and the line can be increased in performance.

3. Implementation of kaizen and proposed improvements with line balancing is only recognized in the PA64LL line brushes and not in all lines. Therefore, it is recommended that the implementation of kaizen and proposed improvements with line balancing be carried out across all lines so that the impact can be felt.

\section{REFERENCES}

[1] Adnan, A. N., Jaffar, A., Yusoff, N., \& Halim, N. H. (2013). Implementation of Continuous Flow System in Manufacturing Operation. Applied Mechanics and Materials, 393 (1), 9-14.

[2] Haekal, J., Hanum, B., \& Adi Prasetio, D. E. 2020. Analysis of Operator Body Posture Packaging Using Rapid Entire Body Assessment (REBA) Method: A Case Study of Pharmaceutical Company in Bogor, Indonesia. International Journal of Engineering Research and Advanced Technology - IJERAT (ISSN: 2454-6135), 6(7), 27-36.

[3] Hanum, B., Haekal, J., \& Adi Prasetio, D. E. 2020. The Analysis of Implementation of Enterprise Resource Planning in the Warehouse Division of Trading and Service Companies, Indonesia. International Journal of Engineering Research and Advanced Technology IJERAT (ISSN: 2454-6135), 6(7), 37-50.

[4] Kholil, M., Haekal, J., Eko Adi Prasetio, D., \& Sulaiman Hasan. 2020. The Lean Manufacturing Design for Improving Production Scheduling Using Product Wheel Method in Chemical Manufacturing Company, Indonesia.International Journal of Engineering Research and Advanced Technology - IJERAT (ISSN: 2454-6135), 6(8), 12-18.

[5] Haekal, J., \& Setio, H. 2017. Selection of Raw Material Suppliers Using Analytical Hierarchy Process in Food and Beverage Company, South Jakarta. ComTech: Computer, Mathematics and Engineering Applications, 8(2), 63-68 
[6] HAEKAL, J. (2018). PERANCANGAN DAN EVALUASI IMPLEMENTASI SISTEM MANAJEMEN MUTU ISO 9001: 2015 MELALUI KEPUASAN PELANGGAN DI UNIVERSITAS ISLAM AS-SYAFI'IYAH

(Doctoral dissertation, Universitas Mercu Buana Jakarta).

[7] Kholil, M., Haekal, J. H, Sulaiman. 2020. Lean Manufacturing Design to Reduce Waste in Gear Production Process Using VSM and Kaizen Method Approaches (Case Study: Gear Primary Driven K56 Product). Journal of Scientific and Engineering Research. 7(8), 1-9

[8] Haekal, J., \& Prasetio, D. E. A. Planning Of Production Facilities Layouts In Home Industry With The Systematic Layout Planning Method.

[9] haekal, J., \& Setiawan, I. (2020). Comparative Analysis of Raw Materials Control Using JIT and EOQ method For Cost Efficiency of Raw Material Supply in Automotive Components Company Bekasi, Indonesia. International Journal of Engineering Research and Advanced Technology (ijerat), 6(10), 7682. https://doi.org/10.31695/IJERAT.2020.3661

[10] Haekal, J., Hanum, B., \& Adi Prasetio, D. E. 2020. Application of Quantitative Strategic Planning Matrix (QSPM) For Determination of Alternative Strategies in Food and Beverage SMES in Bogor Indonesia. Journal of Scientific and Engineering Research. 7(7), 137-145

[11] Hanum, B., Haekal, J., \& Adi Prasetio, D. E. 2020. SPHC Material Inventory Control Analysis in Project VL01 Centralized by the EOQ Method in Automotive Company Indonesia. Journal of Scientific and Engineering Research. 7(7), 130-136

[12] Ikatrinasari, Z. F., Hasibuan, S., \& Kosasih, K. (2018, November). The implementation lean and green manufacturing through sustainable value stream mapping. In IOP Conference series: materials science and engineering (Vol. 453, No. 1, p. 012004). IOP Publishing.

[13] Almamlook, R., Alden, A. Y. Q., Frefer, A., KNEW, S., \& AGARW, Y. (2019). A Simulation Model for Productivity Efficiency Improvement Using Pro-Model: Case Study of Pipe Factory. Revista Austral de Ciencias Sociales, 26(1), 133-142.

[14] Arman H N and Yudha P (2008). Perencanaan dan Pengendalian Produksi. Yogyakarta: Graha Ilmu.

[15] Azwir, H. H., \& Pratomo, H. W. (2017). Implementasi Line Balancing untuk Peningkatan Efisiensi di Line Welding Studi Kasus: PT X. Jurnal Rekayasa Sistem Industri, 6(1), 57-64

[16] Fardiansyah, I., \& Widodo, T. (2018). Peningkatan Produktivitas Menggunakan Metode Line Balancing Pada Proses Pengemasan di PT. XYZ. Journal of Industrial Manufacturing, 3(1). 57-62
[17] Fera, M., Greco, A., Caterino, M., Gerbino, S., Caputo, F., Macchiaroli, R., \& D'Amato, E. (2020). Towards Digital Twin Implementation for Assessing Production Line Performance and Balancing. Sensors, 20(1), 97.

[18]Gaspersz, V. (2003). Total Quality Management. Jakarta: Gramedia

[19] g Crank Case diPT. Ganteng Jaya Motor. Jurusan Teknik Industri. Universitas Katolik Parahyangan, Bandung.

[20] Harrell, Charles, B. K. Ghosh, dan R. Bowden. (2000). Simulation Using ProModel, ed. ke-3. Boston: McGrawHill.

[21] Indrawan, Yayan \& Hariastuti, Ni Luh Putu. (2013). Minimalisasi Bottleneck Proses Produksi dengan Menggunakan Metode Line Balancing. Teknik Industri, Institut Teknologi Adhi Tama, Surabaya.

[22] Liker, J. (2004). The toyota way. 14 management principles from the world's Greatest Manufacturer New York: McGraw-Hill

[23] Manaye, A., Negash, M., \& Alebachew, M. (2019). Effect of degraded land rehabilitation on carbon stocks and biodiversity in semi-arid region of Northern Ethiopia. Forest Science and Technology, 15(2), 70-79.

[24] Mukund Nilakantan, J., \& Ponnambalam, S. G. (2016). Robotic U-shaped assembly line balancing using particle swarm optimization. Engineering Optimization, 48(2), 231-252.

[25]Ristumadin, I. (2015). Analisa Produktivitas dan Efisiensi Kerja Dengan Line Balancing Pada Area Lead Connection di PTA. Penelitian dan Aplikasi Sistem dan Teknik Industri, 9(3), 300-310.

[26] Rosnani G (2007) Sistem Produksi. Yogyakarta: Graha Ilmu

[27] Puteri, R. A. Mahaji dan Wiwik Sudarwati, (2016) Pengukuran Keseimbangan lintasan dan Simulasi Promodel Di PT. Caterpillar Indonesia. Jurnal Integrasi Sistem Industri, 3, 15-22.

[28] Saiful, dkk (2014). Penyeimbangan Lintasan Produksi dengan Metode Heuristik (Studi Kasus PT XYZ Makassar). Teknik Industri. Universitas Hasanuddin, Makassar.

[29] Trenggonowati, D. L. (2017). Simulasi Sistem Proses Produksi di PT. Jakarta Cakratunggal Steel Mills. Jurnal Ilmiah Teknik Industri, 4(1),9. 